\title{
Professor Reynold A. Nicholson, Litt.D., LL.D., F.B.A.
}

The Society has lost in R. A. Nicholson a Gold Medallist, and a man who had for many years assisted in its counsels. The world has lost a scholar who in his own field was the greatest of his generation.

Born on 19th August, 1868, Nicholson was educated at Aberdeen University and at Trinity College, Cambridge. After proving his distinction in Classics, he turned to Persian and Arabic and quickly made his mark. From a Fellowship at Trinity he went to University College, London, as Professor of Persian in 1901, but returned to Cambridge the following year to teach Persian there. He succeeded E. G. Browne as Sir Thomas Adams Professor of Arabic in 1926, and retired under the age-limit in 1933. He left Cambridge in 1940 and passed the last years of his life at Towyn. He died at Chester on 27th August, 1945.

While Nicholson was an admirably exact scholar in Arabic and Persian, philology as such made little appeal to him ; like so many of our great orientalists he was more concerned with ideas than words. Poetry, philosophy, and mysticism were his main interests, and especially the last. His underlying motive in making this choice was expressed simply and frankly in a broadcast he made during the recent war. "As is well known, the doctrines and speculations of the Sufis affected Islam powerfully. To some extent they provide a common ground where men of diverse faiths, while remaining loyal to the creed they profess, can meet in a spirit of tolerance and mutual understanding and thus learn to know and like each other better. If my work has helped in any way towards such an understanding, it has not been done in vain." Nicholson was a prolific worker. It is the hope of the writer to issue a complete bibliography of his writings later; here there is only room to mention the most important. He would himself have singled out for first mention his monumental edition, with translation and commentary, of the Mathnawi $i$ ma'nawi of Jalāl al-Dīn Rūmī: this labour occupied the last twenty years of his active life and will never be surpassed. Nicholson counted as his second most important work the Literary History of the Arabs, and few would dispute his judgment: it is a book abounding in erudition and exhibiting excellent literary taste. Nicholson reckoned third his translations: certainly very few have equalled him in 
this regard, and his renderings of the Arab and Persian poets into verse make delightful reading. The general discriminating public has much to thank him for: the debt of the specialists is no less great. His judgment was as sound as his scholarship, his learning as profound as his application.

As a teacher Nicholson was admirable: to beginners he was understanding and sympathetic, to advanced students he was inspiring and ungrudging in his aid. The rare public lectures he gave were always thronged, and he gave his audiences much to delight them. His shy and retiring manner concealed many great qualities which only a few were privileged to know: they will bear witness to his deep spirituality, his true goodness, and his loyal friendship.

A. J. Arberry.

\section{Dr. Nicolaas Johannes Krom}

Nicolaas Johannes Krom was born at 'sHertogenbosch on 5th September, 1883. He studied classics at the University of Leiden, taking Sanskrit and comparative philology, and qualified for his doctor's degree in 1908. Selected to succeed Dr. Brandes as Director of Archæology in Netherlands India, he took up the difficult study of Old Javanese. The years 1910-15 Krom spent in Java, where he made himself familiar with the numerous Hindu remains, his primary duty being the organization of a permanent Archæological Survey. In 1919 he was appointed at Leiden to the newly founded chair for the archæology and ancient history of Netherlands India. His lectures were attended by students reading for the Civil Service, and particularly by future members of the Archæological and Linguistic Surveys.

Krom's fame as the great authority on the antiquities of Indonesia is mainly due to three works of outstanding merit. Best known is his magnum opus on the Barabudur, grand monument of the Mahāyāna. The iconological description of this gigantic stüpa with: ts 1,500 large sculptured panels appeared in 1920. A somewhat abbreviated English version followed in 1927. Krom not only summarized all that had been written on the subject, but added much that was new, e.g. an interpretation of the series of reliefs illustrating the Gandavyüha. 